\title{
Justice for Iowa: \\ Samuel Freeman Miller's \\ Appointment to the United States Supreme Court during the Civil War
}

\author{
MichaEl A. RosS
}

DURING THE SPRING OF 1862, three seats on the United States Supreme Court sat empty, even though the Court would soon hear arguments in cases that would decide the constitutionality of President Lincoln's controversial war measures. Despite the critical need for Republican voices on a Court dominated by Democrats and southerners, Lincoln had postponed making nominations to the Court while he waited for Congress to pass a judicial reorganization bill that would reduce the number of southern seats on the supreme bench. Because the Court had long been a bastion of proslavery sentiment, Lincoln favored a thorough restructuring of the judicial circuits that would give the Court a permanent northern majority and prevent its justices from ever again issuing such an infamous decision as Dred Scott v. Sandford. Lincoln thus hoped Congress would quickly pass a judicial reorganization bill that would allow him to begin to reshape the Supreme Court in the Republicans' image.

Despite the urgency of the situation, however, Iowa's congressional delegation, led by Senator James Grimes and Congressman James Wilson, purposefully delayed the proposed

I would like to thank William Barney, Peter Coclanis, Marvin Bergman, Kathleen Blain Roberts, and the anonymous referees of the Annals of Iowa for their helpful comments on this article. I also gratefully acknowledge that a grant from the State Historical Society of Iowa helped to fund the research.

THE ANNALS OF IOWA 60 (Spring 2001). (C) The State Historical Society of Iowa, 2001. 
judicial reorganization bill for months. They did so even though it meant that key seats on the Court would remain unfilled and that Chief Justice Roger Taney and the other pro-southern members of the Court might declare some of Lincoln's war measures to be unconstitutional. The purpose of this article is to explain why Grimes and Wilson-both of whom were staunch Republicans and supporters of the Union war effort-delayed the reorganization bill and how their efforts eventually led President Lincoln to appoint Keokuk's Samuel Freeman Miller to the nation's highest tribunal. In contrast to earlier treatments of these developments, which suggest that the Iowans' efforts were merely machinations designed to get a personal friend appointed to the bench, this article will show that ideological imperatives drove the campaign to appoint Miller, and it reflected significant regional and ideological fissures within the Republican Party. ${ }^{1}$

ABRAHAM LINCOLN came to the presidency in 1861 deter-
mined to reshape the Supreme Court. The Court had, after all,
helped to precipitate the crisis that engulfed the nation, and
many northerners viewed Roger Taney's 1857 opinion in Dred
Scott as the proximate cause of the war. That opinion ruled that
African Americans could not be citizens of the United States
and that Congress could not prohibit the expansion of slavery
into the territories. ${ }^{2}$ Lincoln regarded the Dred Scott decision as

1. Several historians have noted the extraordinary efforts Iowa's congressional delegation made to delay judicial reorganization and to ensure Miller's appointment. These scholars have, however, minimized or ignored the Iowans' ideological motivations. David Silver, for example, argues that Senator Grimes's goal in delaying judicial reorganization was "an appointment for his friend Samuel F. Miller." This explanation, although partially correct, fails to explain the larger ideological and economic forces that led Iowa's delegation to fight so long and so hard, even when they knew doing so might jeopardize Lincoln's war powers. David M. Silver, Lincoln's Supreme Court (Urbana, IL, 1956), 51-53. The portion of Silver's book dealing with Miller's appointment was reprinted as "Lincoln's Appointment of United States Justice Samuel F. Miller" in Annals of Iowa 33 (1957), 510-25. See also Stanley I. Kutler, Judicial Power and Reconstruction Politics (Chicago, 1968), 16, 17; and Henry J. Abraham, Justices, Presidents, and Senators: A History of U.S. Supreme Court Appointments from Washington to Clinton, rev. ed. (Lanham, MD, 1999), 88.

2. Dred Scott v. Sandford, 19 How. (60 U.S.) 393 (1857); Paul Finkleman, Dred Scott v. Sandford: A Brief History with Documents (Boston, 1997), 29. 
so inflammatory, so clearly biased, that he-and other Republicans-refused to defer to the judgment of the nation's highest tribunal. Instead, he declared that Dred Scott was wrong and that it should be overturned. "We think the Dred Scott decision is erroneous," he had argued in 1858. "We know the Court that made it has often over-ruled its own decisions and we shall do what we can to have it . . . over-rule this. ${ }^{\prime 3}$ While campaigning in 1860, Lincoln and other Republicans had pledged to "reconstitute" the Court if their party captured the presidency. Now, as president, Lincoln hoped to fulfill that pledge. ${ }^{4}$

Once in office, Lincoln had immediate opportunities to leave his imprint on the Court. When he arrived at the White House, the Court already had one vacancy. Justice Peter Daniel of Virginia, a member of the Dred Scott majority and "a brooding proslavery fanatic" had died the previous May. President Buchanan, overwhelmed by sectional pressures, had simply left the seat empty. ${ }^{5}$ One month into Lincoln's presidency, a second seat on the Court opened. On April 4, 1861, Justice John McLean of Ohio died at the age of 76. A dissenter in Dred Scott, McLean was a hero to many abolitionists, and he would have been a friend of the new administration. Although Republicans mourned his loss, his departure did mean that Lincoln could now fill two seats on the Court with energetic, younger justices of his own choosing. ${ }^{6}$ Later in April, yet another seat on the Court opened when Justice John A. Campbell of Alabama, a member of the Dred Scott majority, resigned to join the Confederacy. Thus, as the nation descended into Civil War, some solace could be taken in the loosening of the South's control of the Supreme Court. Lincoln would now have the opportunity to appoint one-third of the Court's justices.

3. Roy P. Basler, ed., The Collected Works of Abraham Lincoln, 9 vols. (New Brunswick, NJ, 1953-1955), 2:401 (hereafter cited as Collected Works); James M. McPherson, Battle Cry of Freedom: The Civil War Era (New York, 1988), 176.

4. McPherson, Battle Cry of Freedom, 177.

5. Don E. Fehrenbacher, The Dred Scott Case: Its Significance in American Law and Politics (New York, 1978), 234; McPherson, Battle Cry of Freedom, 174; Silver, Lincoln's Supreme Court, 3.

6. Silver, Lincoln's Supreme Court, 9, 10.

7. Ibid., 10. 
Even with these three vacancies, however, Lincoln still faced a hostile Court, one unlikely to approve of Republican war measures or to overturn Dred Scott. Of the remaining six justices, five-James Wayne, John Catron, Roger Taney, Robert Grier, and Samuel Nelson-had been in the Dred Scott majority, and the sixth-Nathan Clifford of Maine-was an embittered, proslavery Democrat. Even if Lincoln appointed three zealous Republicans, the Court's majority would still comprise men unsympathetic to Lincoln and his party. If Lincoln needed confirmation of this fact, it came very early with Roger Taney's opinion in Ex Parte Merryman, in which the chief justice ruled that the president did not have the power to suspend habeas corpus, even during a national emergency. ${ }^{8}$

Although Lincoln ignored Taney's Merryman decision, he knew that the Court would surely continue to attempt to check presidential war powers. Lincoln recognized that a civil war required drastic measures, and he often ignored constitutional niceties. With the list of controversial measures growing rapidly, each new directive that left his desk increased the possibility of a major confrontation with the Supreme Court. During the early months of the war, Lincoln ordered the Union navy to blockade southern ports, and he had several members of the Maryland legislature arrested for their political views. In October 1861 he suspended habeas corpus all along the eastern seaboard from Washington to Bangor, Maine - even though the northeastern states were not in rebellion. And although Congress reconvened for an emergency session in the summer of 1861 and promptly passed bills approving Lincoln's extraconstitutional actions, the constitutionality of many of the president's war measures remained in doubt. Clearly, at some point, many of Lincoln's policies would face the judicial scrutiny of the Supreme Court. ${ }^{9}$

TANEY'S MERRYMAN OPINION, combined with lingering anger over Dred Scott, also fueled new calls by Republicans to pack the Court with Lincoln appointees. The New York Tribune

8. Ex Parte Merryman, F. Cas. 9487 (1861).

9. Mark E. Neely, The Fate of Liberty: Abraham Lincoln and Civil Liberties (New York, 1991), 14, 15, 24. 
proposed increasing the number of seats on the Court to eleven, justifying its position by pointing to the role Dred Scott had played in causing the war. "The present rebellion," the Tribune noted in its defense of the court-packing plan, "is due quite as much to an unsound and unwise decision of the Supreme Court as to any other single cause. ${ }^{\prime 10}$

In December 1861, Republican Senator John P. Hale of New Hampshire revealed an even more radical plan for reconstituting the Court. Hale offered a resolution directing the Senate Judiciary Committee to inquire into the possibility of "abolishing the present Supreme Court" and starting from scratch with a new Court. And where, observers wondered, would the Congress find the authority for this audacious plan? Hale cited Article III, Section One, of the Constitution, which states, "The judicial power of the United States shall be vested in one Supreme Court, and in such inferior courts as the Congress may, from time to time, ordain and establish." Hale interpreted this to mean that Congress could establish new Supreme Courts from "time to time." "My idea," Hale blustered, "is that the time has come." Moderate Republicans, however, viewed Hale's plan as extreme and stifled it in committee."

Proponents of a less radical plan for restructuring the Court met with more success. They proposed reorganizing the nation's judicial circuits in order to decrease the South's disproportionate representation on the Court. In 1861 the nation's federal courts were divided into nine judicial circuits, five of which encompassed slaveholding states. Each circuit was supervised by a justice of the United States Supreme Court. In most cases, the supervising justice hailed from the region he supervised. ${ }^{12}$

It had been 25 years since the last modification of the circuits. During that time, the North's population had exploded, while the South's had lagged behind. The resulting imbalance between population and representation on the Court infuriated northern-

10. New York Tribune, 13 December 1861. See also Chicago Tribune, 4 March 1861; Ferhenbacher, Dred Scott, 576-77; Silver, Lincoln's Supreme Court, 39, 40.

11. Congressional Globe, 37th Cong., 2d sess., 1861, 26-28, 37, 155; Silver, Lincoln's Supreme Court, 42, 43; Fehrenbacher, Dred Scott, 576-77.

12. Taney issued his decision in Ex Parte Merryman in his capacity as a circuit court judge. 


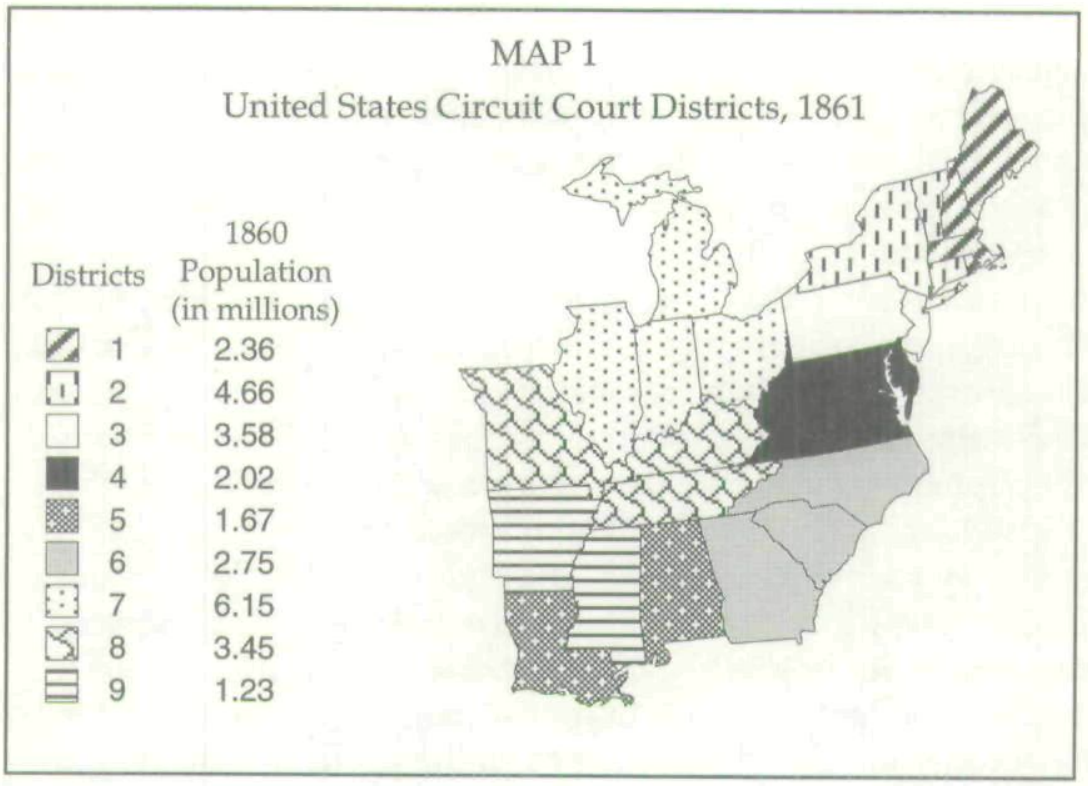

ers. "The twenty millions of the people of the free states are represented by four judges," the Chicago Tribune complained, "while the nine millions of whites in the South have five judges. ${ }^{\prime 13}$ Like the notorious three-fifths clause in the Constitution, which allowed the South to include slaves in the population totals used to determine representation in the House of Representatives, the organization of the judicial circuits seemed to give the slave states an unfair advantage. The population of the Seventh Circuit alone (Ohio, Indiana, Illinois, and Michigan) equaled that of the five southern circuits combined. Such disparity led Iowa's Congressman James F. Wilson to call the Court a "monstrous citadel of slavery." ${ }^{14}$

In addition to the sectional imbalance, reorganization was overdue as a result of the nation's westward expansion. Texas, Florida, Wisconsin, Oregon, Minnesota, Kansas, California, and Iowa had not yet been assigned to circuits. Proponents of change could thus cite both practical and political justifications for a major judicial reorganization.

13. Chicago Tribune, 5 June 1862.

14. Keokuk Gate City, 29 July 1862. 
Abraham Lincoln joined the chorus of voices calling on Congress to reorganize the circuits and vowed to delay making any appointments to the Court until that task was accomplished. In his first annual message to Congress, in November 1861, Lincoln announced his support for a plan that would reduce the number of southern circuits and increase those from the North. Pointing to the North's tremendous growth, Lincoln noted that during Justice McLean's tenure the population of the Seventh Circuit had grown from 1,470,000 to 6,151,000, a circuit "altogether too large for any one Judge." A change had to be made. Efficiency, logistics, and simple fairness all pointed to the need for reorganization. Because two of the three vacant seats on the Court had been held by southerners, moreover, those justices' former circuits could now be condensed with minimal disruption to the circuits of the sitting justices. ${ }^{15}$

The Congress heeded Lincoln's call. Six days after the president's speech, Senator John Sherman of Ohio introduced a bill to reorganize the circuits to consolidate the southern circuits and add a new circuit in the North. The Senate referred the bill to its Judiciary Committee, while in the House, Representative John Bingham of Ohio introduced a bill similar to Sherman's. ${ }^{16}$ After a month of deliberations, the Senate Judiciary Committee endorsed Sherman's proposal. Under Sherman's plan, three judicial circuits would be assigned to the Northeast (population 10.6 million); three would cover the South (population 9.9 million); and three would represent the West (population 10 million). Under this plan, all three vacancies on the Court would be in western circuits. Lincoln's appointments, therefore, would have a profound effect on the administration of justice in that region. ${ }^{17}$

With a plan on the table, members of the Judiciary Committee urged their fellow senators to approve the bill quickly. Because Lincoln had postponed making appointments until the reorganization of the circuits was complete, the Court had oper-

15. Lincoln's first annual message to Congress, 3 December 1861, in Collected Works, 5:35-53.

16. The bill was titled An Act to Amend the Judicial System of the United States. Silver, Lincoln's Supreme Court, 50, 51.

17. California and Oregon would, for the time being, be left out of the circuit system. 


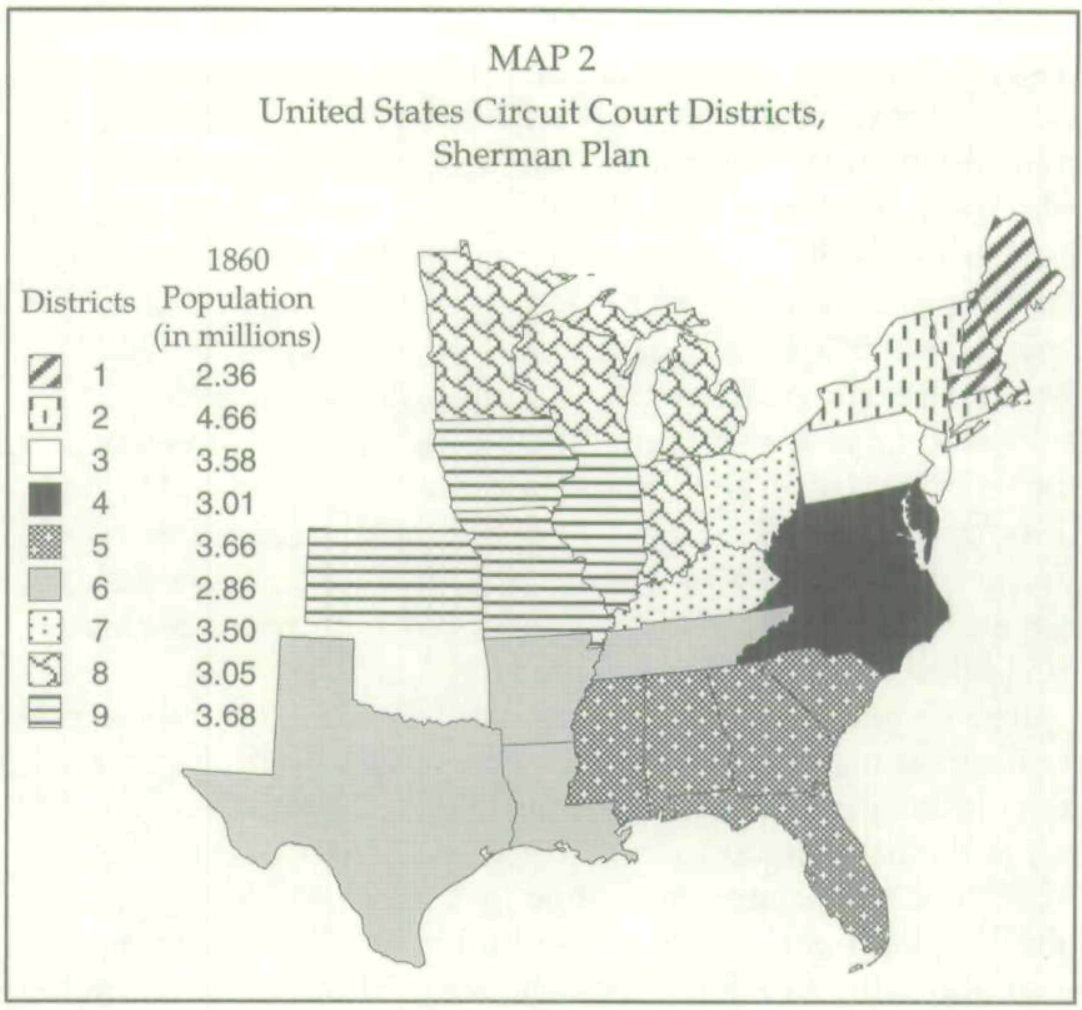

ated for almost a year with only six members. With the constitutionality of Lincoln's war measures hanging in the balance, many senators hoped for quick passage of the plan so that Republican appointees could reshape the Court's jurisprudence. ${ }^{18}$

DESPITE THE NEED FOR EXPEDIENCY, the judicial reorganization bill met stiff opposition from an unexpected source: Iowa's Republican congressional delegation. In the midst of the Civil War-a crisis that had created a pressing need for Republican justices on the Court-Iowa's delegation delayed the circuit reorganization bills in the House and Senate for months, even though doing so meant that three seats on the Supreme Court would go unfilled. Congressman James Wilson had

18. Congressional Globe, 37th Congress, 2 d sess., 1861, 187-88, 469. 


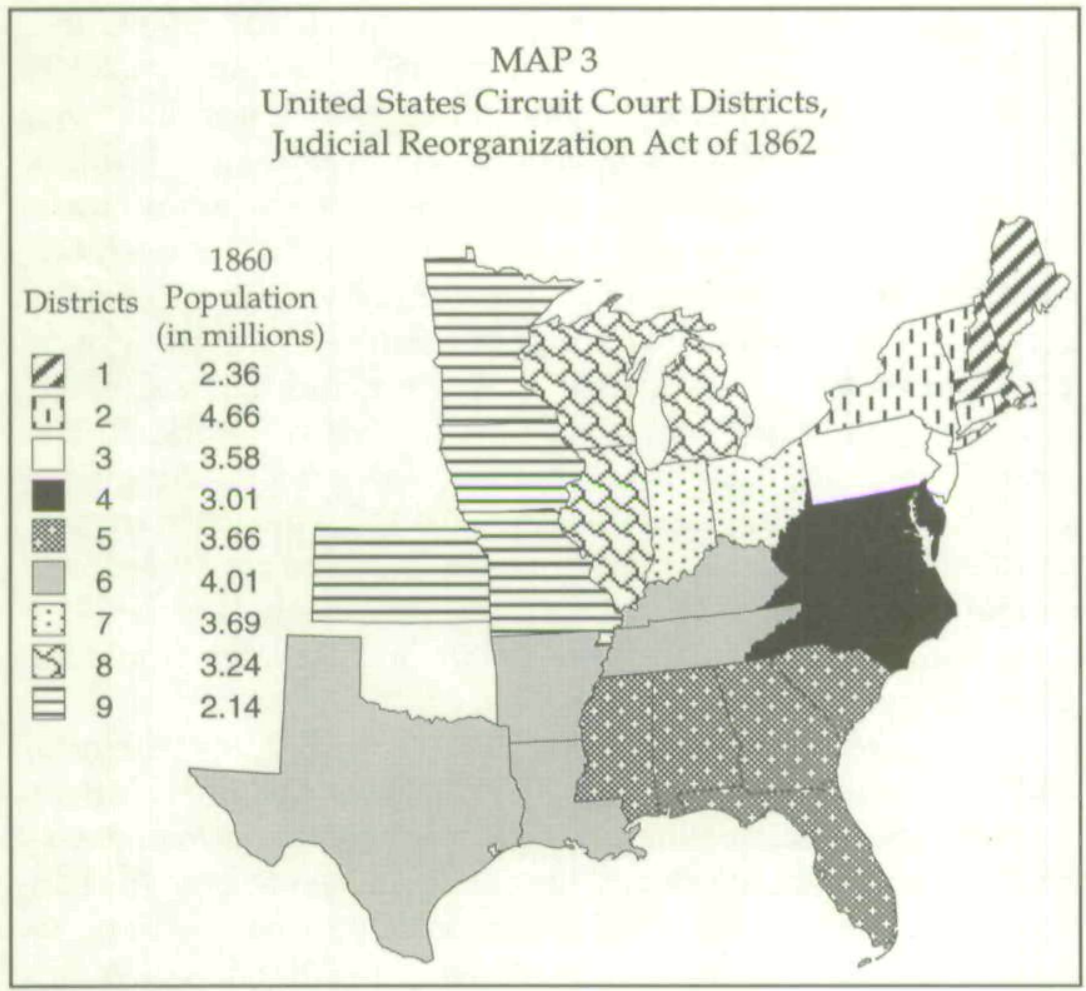

particular success in keeping the House version of the bill "bottled up in committee.."19

Although Iowa's senators and congressmen welcomed the idea of reorganizing the circuits, they resisted the Senate Judiciary Committee's plan to place the Hawkeye State in the new Ninth Circuit with Illinois. Because of the economic and political importance of Chicago and the rest of Illinois, Lincoln would almost certainly appoint a justice from his home state to supervise the circuit. Already rumors were swirling that Lincoln would nominate his friend Senator Orville Browning for the position. Indeed, Lincoln had told others that he felt he "must appoint Browning. ${ }^{20}$

\section{Silver, Lincoln's Supreme Court, 52.}

20. Noah H. Swayne to Benjamin F. Wade, 10 January 1861, Wade Manuscript Collection, Library of Congress; Silver, Lincoln's Supreme Court, 51, 60. 
Many Iowans knew Browning well and held unfavorable opinions of him. In the campaign of 1860, Browning spoke at Republican rallies in Keokuk and other Iowa cities and even stayed at Samuel Miller's house. (Miller was then a Keokuk lawyer and Republican organizer.) Most Iowa Republicans shared Browning's moderate views on slavery, but his positions on other issues made him suspect. Before serving in the Senate, Browning was a wild-eyed booster of railroads. With his friends he had promoted the Northern Cross, a railroad that had relied heavily on community subscriptions to railroad stock. In the 1850 s, Browning had traveled from town to town giving speeches encouraging local governments to go into debt to support the Northern Cross's construction. But after the river-town economies crashed in 1857, Browning steadfastly opposed the repudiation of bonds and other debts, and he later would be hostile to the regulation of railroads. ${ }^{21}$

During the 1850 s, many Iowa counties and towns had gone heavily into debt in a frenzied effort to bring railroads to their communities. Municipalities helped fund private railroad enterprises by issuing bonds, using the money raised to buy stock in the railroad companies. When the economy turned sour, however, those public debts destroyed the grand dreams of many communities. When eastern bondholders refused to renegotiate those debts, Iowans grew embittered and turned to the courts for relief. In 1862 the Iowa Supreme Court granted their wishes by ruling that the bonds were void because county and town officials never had constitutional authority to issue the bonds. ${ }^{22}$ Out-of-state bondholders then sued in federal court to force the Iowans to pay their debts. Because the U.S. Supreme Court would soon be hearing numerous cases involving Iowa railroad bonds and other cases that pitted Iowa steamboat corporations against Illinois railroads, Iowans hoped to avoid being saddled with a justice like Orville Browning who would be unsympathetic to their economic concerns.

21. Maurice G. Baxter, Orville H. Browning: Lincoln's Friend and Critic (Bloomington, IN, 1957), 57, 68, 111, 224.

22. The State of Iowa ex rel. v. The County of Wapello, 13 Iowa R. 388 (1862); Michael A. Ross, "Cases of Shattered Dreams: Justice Samuel Freeman Miller and the Rise and Fall of a Mississippi River Town," Annals of Iowa 57 (1998), 227-39. 
At the end of January 1862, as it became clear that the reorganization of the circuits would be delayed, Lincoln was compelled to make a nomination to fill John McLean's vacant seat on the Court. (McLean's Seventh Circuit then consisted of Ohio, Indiana, Illinois, and Michigan). Lincoln had hoped to wait until reorganization was complete, but when Justices Taney and Catron became ill, the already depleted Court could not maintain a quorum. ${ }^{23}$ For the position, Lincoln chose Noah Swayne, a Republican from Ohio with impressive antislavery credentials. Like Samuel Miller, Swayne had been born in a slaveholding state, studied medicine, switched to law, acquired slaves through marriage, and then emancipated them. Eventually, he moved to Ohio, where he helped form the state's Republican Party and served as counsel in fugitive slave cases. Swayne's sterling Republican credentials allowed Lincoln to assume (correctly, as it turned out) that Swayne would, if appointed, uphold his war measures. ${ }^{24}$

There was more to Swayne, however, than just his antislavery views. As an attorney, Swayne had grown wealthy representing railroads, banks, and other corporations, and he embraced the economic outlook of America's financial elites. In 1856, for example, Swayne defended the Mad River and Lake Erie Railroad in a suit brought by a company brakeman who had been thrown under a train and maimed as a result of defective brake rods. In the well-publicized case that followed the accident, Swayne successfully argued that by agreeing to be hired, the brakeman had voluntarily assumed the risk of injury and should not be compensated for his injuries. ${ }^{25}$

Swayne also had close ties to New York City wealth. Samuel J. Tilden, a Democrat and leading New York corporate lawyer, ac-

\section{Silver, Lincoln's Supreme Court, 51.}

24. Richard L. Aynes, "Constricting the Law of Freedom: Justice Miller, the Fourteenth Amendment, and the Slaughter-House Cases," Chicago-Kent Law Review 70 (1994), 674, 675; Jonathan Lurie, Noah Haynes Swayne, in The Oxford Companion to the Supreme Court, ed. Kermit Hall (New York, 1992), 850.

25. Mad River and Lake Erie R.R. v. Barber, 5 Ohio State Reports 541 (1856). For a more detailed discussion of cases of this type, see John Williams-Searle, "Courting Risk: Disability, Masculinity, and Liability on Iowa's Railroads, 1868-1900," Annals of Iowa 58 (1999), 27-77. 
tively lobbied for him. The New York bar also petitioned Lincoln on Swayne's behalf. Capitalists who supported Swayne weighed in as well. Chicago railroad magnate William B. Ogden, the first president of the Union Pacific, urged Swayne's nomination. In a letter to Lincoln, Ogden pointed out that Swayne's considerable fortune meant that "he has means to live handsomely independent of his salary." ${ }^{26}$

With Swayne's appointment, Ogden and other captains of industry got their wish. "The war could not be prosecuted to a successful conclusion without the support of Big Business," one historian has noted, and Swayne's selection "satisfied business interests at the same time that [it] satisfied Ohio politicians. ${ }^{\prime 27}$

With Swayne appointed and Browning rumored as a shooin for a reorganized Illinois circuit, Iowans dug in their heels and campaigned for a reorganization bill that would create a new trans-Mississippi circuit. They hoped that a circuit made up solely of western river states, not including Illinois, would get a presiding justice more sympathetic to their economic needs. In March Iowa's state legislature passed a resolution urging its congressmen (and requiring its senators) to fight for a circuit made up solely of states west of the Mississippi. They also petitioned Congress asking for the same. ${ }^{28}$

Unified and determined, Iowa's congressional leaders, led by Senator James Grimes and Congressman James Wilson, stymied the plan that put Iowa in the same circuit as Illinois. Although once a promoter of railroads while living in Burlington in the 1850s, Grimes-publicly at least-turned against railroads, bondholders, and capitalists after the Panic of 1857 . Wilson, like Grimes, had also turned against railroads and financiers after the Panic, and in 1860 he supported a controversial plan to regulate railroad rates. Now in Congress, Wilson served as a

26. Silver, Lincoln's Supreme Court, 59; W. B. Ogden to A. Lincoln, 25 May 1861, quoted in Carl B. Swisher, The Taney Period, 1836-64 (New York, 1974), 816.

27. Ernest Sutherland Bates, The Story of the Supreme Court (Indianapolis, 1936), 168; Silver, Lincoln's Supreme Court, 59.

28. Senate Misc. Document No. 73, 37th Cong., 2d sess., p. 1. At that time, senators were selected by state legislatures rather than by a direct vote of the people. As a result, legislators had the leverage to demand that their senators follow their wishes on key issues. 
member of the House Judiciary Committee, a strategic position from which to influence the reorganization process. ${ }^{29}$

Rather than placing Iowa in a circuit with Illinois, Wilson and Grimes proposed creating a new Ninth Circuit out of Iowa, Missouri, Minnesota, and Kansas. They argued that the four states shared similar legal codes and that "their commercial relations were closely connected by the Mississippi and Missouri Rivers. ${ }^{\prime 30}$ Despite all the manic efforts to bring railroads and eastern capital to Iowa in the 1850s, Iowa's leaders still felt more kinship to states built on the steamboat trade, states that now felt the effects of the river trade's decline and the burden of railroad debt.

Wilson also reminded his House colleagues of the crucial role Iowa's troops were playing in the war and suggested that the bravery of Iowa's soldiers entitled Iowans to the judicial circuit of their choice. Wilson noted that Iowa had sent "to aid in crushing the atrocious rebellion, almost as many men as she had voters in 1850; men than whom none more true, none more brave, none more gallant ever encountered a foe on this field of battle. The bloody fields of Pittsburgh Landing, Fort Donelson, Belmont, Wilson's Creek, and Blue Mills, all attest how well and nobly the gallant volunteers of Iowa have done." Wilson failed to explain why "the gallant volunteers of Iowa" should not share a judicial circuit with the gallant volunteers from Illinois, but he may have realized that discussions of the Rock Island Bridge, bond repudiation, railroads, or capitalists would not have sounded as patriotic or persuasive. ${ }^{31}$

As the Iowans successfully delayed the reorganization bills, Republican Senator Jacob Howard of Michigan, a member of

29. Robert Cook, Baptism of Fire: The Republican Party in Iowa, 1838-1878 (Ames, 1994), 103, 107, 109, 123; Fred B. Lewellen, "Political Ideas of James W. Grimes," Iowa Journal of History and Politics 42 (1944), 339-404; Silver, Lincoln's Supreme Court, 55. For a sketch of Wilson's career, see Leonard Schlup, "Republican Loyalist: James F. Wilson and Party Politics, 1855-1895," Annals of Iowa 52 (1993), $123-49$.

30. Iowa Congressman James F. Wilson, Speech, 4 June 1862, Congressional Globe, 37th Cong., 2d sess., p. 2562; Swisher, The Taney Period, 826; Charles Fairman, Mr. Justice Miller and the Supreme Court, 1862-1890 (New York, 1973), 47; Silver, Lincoln's Supreme Court, 55.

31. Wilson, Speech, 4 June 1862. 
the Senate Judiciary Committee, questioned their motives and the idea that "there should be a division of judicial circuits upon the Mississippi River." Under the Iowans' plan, Howard noted, the circuits would once again have wildly disproportionate populations. A circuit made up of Missouri, Iowa, Minnesota, and Kansas would represent a population of only 2.1 million, while Michigan's circuit and the circuit covering Indiana and Ohio would have 3.2 and 3.7 million residents respectively. Was not one purpose behind reorganization, Howard wondered, to bring circuit court representation in line with population? Under the current system, the South had disproportionate representation. The Iowans' plan would replicate the problem, minus only the disruptive variable of slavery. (Compare maps 2 and 3, above.) "All of these inequalities and disproportions," Howard complained, "are introduced ... for the purpose of carrying out the idea that there must be a separate circuit on the West side of the Mississippi River." "Why are these inequalities introduced?" he asked. "What is at the bottom of it?"

Howard perceptively noted that the issue had broader, and disturbing, implications. In the Iowa plan, Howard saw dangerous sectionalism. By demanding a circuit made up solely of states west of the Mississippi, the Iowans highlighted regional differences and animosities. Against the backdrop of a bloody civil war, such sectional identification made Howard uneasy. "Indeed, I do not like it," Howard admonished. "In times like these I am getting a little distrustful of geographical divisions. We do not know what a day or even an hour may bring forth in the midst of the trials and shocks the nation is now undergoing. ${ }^{\prime \prime 3}$

Howard's concerns reflected an important development within his party. Although Republicans shared a general worldview that celebrated free labor, the party also suffered from significant regional tensions. Republicans often divided over economic issues along East-West, North-South, and urban-rural lines. Debates about taxes and tariffs, for example, split Republicans residing in New England and the upper northwest (Wisconsin, Minnesota, Michigan, and the northern portions of Illi-

32. Congressional Globe, 37th Congr., 2d sess., pp. 3276-78.

33. Ibid., 3278. 
nois and Indiana) from those in the lower portions of Illinois, Indiana, Ohio, and Iowa. ${ }^{34}$ Other issues, particularly railroad bonds, widened cleavages between urban and rural Republicans and between easterners and westerners. Many westerners shared a growing resentment of New York and saw a conflict that pitted eastern speculators, brokers, money-changers, and bondholders against the productive toiling men of the country. ${ }^{35}$ The Iowans' battle over judicial reorganization revealed yet another schism, this one between the steamboat states on the west side of the Mississippi River and the railroad state of Illinois. Reeling from structural changes to the economy and massive debts to railroad bondholders, Iowans sought to avoid the appointment of a pro-railroad justice in their circuit.

From February through May of 1862, the Iowa congressional delegation and their allies successfully stalled the judicial reorganization legislation. In early June the Chicago Tribune asked, "What has become of the bill reorganizing the Supreme Court?" Pointing to the disparities between the North and the South and to all of the western states that had yet to be assigned to a circuit, the Tribune demanded that Congress take action and not "leave the court in this wretched condition." ${ }^{36}$

Under growing pressure, the House and Senate needed to act. In June, despite Grimes's efforts, the Senate rejected Iowa's plan and passed a version of the bill that lumped Iowa with Illinois. But in the House, where Wilson sat on the Judiciary Committee, the bill passed in Wilson's form, with Iowa placed in a judicial circuit with Missouri, Kansas, and Minnesota. When the House and Senate then met in a conference committee on the issue, Wilson went to work. Most of the members of the joint committee hailed from eastern states unaffected by the bill, and they probably would have accepted any version that would allow the drawn-out process to be completed so that new justices could be appointed. Because Wilson stubbornly insisted on his version of the Ninth Circuit, a majority of the

34. Heather Cox Richardson, The Greatest Nation of the Earth: Republican Economic Policies during the Civil War (Cambridge, MA, 1997), 2, 12, 15, 80.

35. Ibid., 13, 80.

36. Chicago Tribune, 5 June 1862. 
other members of the conference committee eventually acquiesced, and the bill emerged with Iowa in a new circuit of states exclusively from west of the Mississippi, while Illinois joined Wisconsin and Michigan in the Eighth Circuit (see map 3 above).

On July 12, Congress passed the Judicial Reorganization Act of 1862 by a unanimous vote in the House and a vote of 24 to 12 in the Senate. Lincoln also approved the measure, and on July 15 , with his signature, the bill became law. The Iowans had "delayed and jeopardized circuit reorganization," but they had won. $^{37}$ Iowa joined a circuit in which three of the four states were tied to the river trade. Iowans now urged Lincoln to appoint a justice who knew the hopes, dreams, and bitter disappointments of the river towns all too well: Samuel Freeman Miller.

MILLER'S SUPPORTERS had begun lobbying for his appointment from the moment Congress started debating judicial reorganization. Iowa judges and lawyers barraged Lincoln with letters that served a dual purpose. Not only did they tout Miller as the right man for the job, they reminded Lincoln that Iowans desired their own circuit and representation on the Court. "The citizens of the Upper Mississippi Valley," wrote one Keokuk lawyer, "believe that this region of the country is entitled to be represented on the federal bench." "I hope your excellency will be pleased to compliment Iowa, whose devotion to our Union is so manifest \& deserving," former Iowa Congressman Daniel F. Miller chimed in, "with the appointment of Mr. Miller." Several letter writers emphasized the steadfast Republicanism of a man who was "an earnest Patriot and conscientious Republican" and "unwavering in his political creed. ${ }^{\prime 38}$

But letters came from Democrats as well as Republicans, reflecting Iowans' recognition that Miller represented their best hope for a sympathetic voice on the Court. Almost all spoke of

37. Silver, Lincoln's Supreme Court, 55.

38. Edward Johnstone to Abraham Lincoln, 20 December 1861, Lincoln Papers, Library of Congress, microfilm, reel 30, doc. 13503; Daniel F. Miller to Lincoln, 10 December 1861, ibid., doc. 13327; C. C. Nourse (Iowa Attorney General) to Lincoln, 14 December 1861, ibid., doc. 13423. 


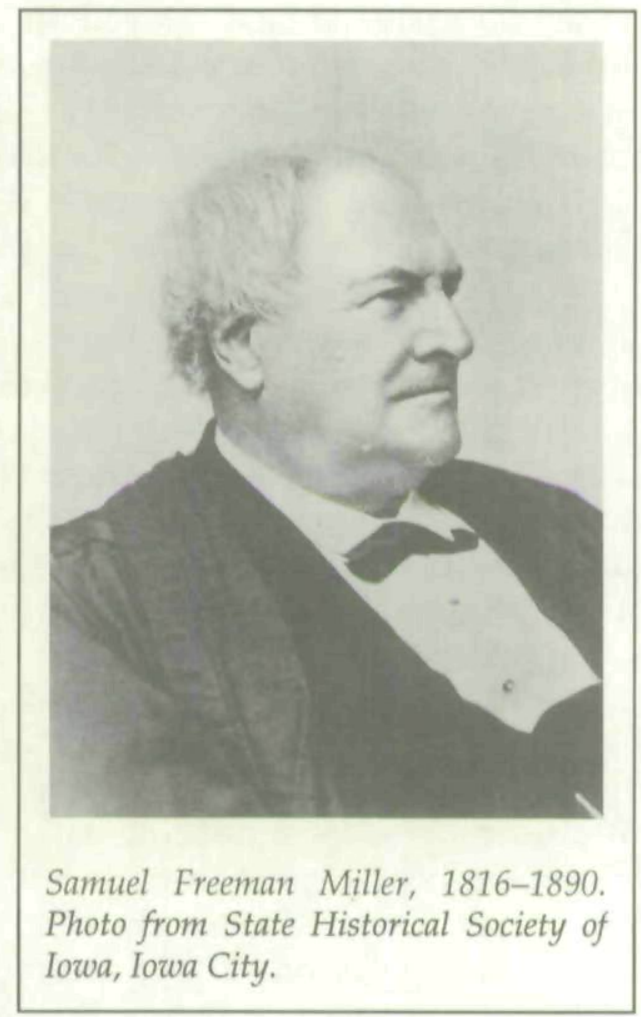

Miller's sharp mind, and many described him as the top lawyer in the state. ${ }^{39}$ Iowa Federal District Court Judge J. M. Love wrote on Miller's behalf, even though as a Keokuk Democrat, Love had sparred with Miller in the past. "Personally I have been a friend of Mr. Miller," Love informed Lincoln, "but politically opposed him." As Keokuk neighbors, however, Love and Miller agreed on certain topics. "As Judge of the District Court of Iowa," Love wrote, Miller had "been engaged in constant and extensive practice before me." In the district court, Judge Love had heard Miller's argument in the Rock Island Bridge case and agreed

39. Joseph C. Knappe (former U.S. Attorney in Iowa) to Lincoln, 4 January 1862, ibid., reel 31, doc. 13822; Caleb Baldwin (Iowa Supreme Court judge) to Lincoln, 16 December 1861, ibid., reel 30, doc. 13424; George C. Wright (Iowa Supreme Court judge) to Lincoln, 16 December 1861, ibid., doc. 13454; Francis Springer (Iowa attorney) to Lincoln, 11 December 1861, ibid., doc. 13368. 
with Miller that the bridge should be destroyed. In his opinion siding with Miller, Love had warned that if he allowed that railroad bridge to stand, "we shall probably, in no great period of time, have railroad bridges upon the Mississippi River at every forty or fifty miles of its course. ${ }^{\prime 40}$ As a river town resident and pro-steamboat judge, Love now wanted Miller on the Supreme Court.

Miller was flattered that so many Iowa Democrats lobbied for his nomination. "It was a time of great political excitement," he later recalled, "and I have always felt peculiarly gratified that members of the bar who were zealous Democrats vied with those of the Republican party, of which I had since its first organization been an active supporter, in the sincerity and vigor of their recommendations. ${ }^{\prime 41}$ The bipartisan support for Miller reflected a regional worldview that Iowa's Democrats and Republicans shared. Outside of Iowa, Democratic Copperheads portrayed Republicans as the party of eastern bondholders and railroad directors who reaped windfall profits from the war, and they claimed that Lincoln's support for tariffs, the national banking system, and government bonds enriched northeastern capitalists at the expense of farmers and laborers. But in Iowa, Republicans shared Democrats' views of bondholders and railroad magnates. When it came to eastern capitalists, Republicans and Democrats in Iowa shared a western, trans-Mississippi perspective. Thus, men of both parties favored Miller's appointment to the Court. ${ }^{42}$

Some Iowans pressed Miller's case in person. Miller himself asked Lincoln's assistant postmaster general, John Kasson of Des Moines, to meet with the president on his behalf. Lincoln, Kasson soon learned, had not heard of Miller and confused him with Daniel F. Miller, who had once represented Iowa in the

40. J. M. Love, 1 January 1862, ibid., reel 31, doc. 13746 (emphasis in original); Ross, "Cases of Shattered Dreams," 221, 231.

41. Albany Law Journal 25 (1879), 20.

42. Eric Foner, Reconstruction: America's Unfinished Revolution, 1863-1877 (New York, 1988), 31; Frank L. Klement, "Economic Aspects of Middle Western Copperheadism," Historian 14 (1951), 27-44; idem, "Middle Western Copperheadism and the Genesis of the Granger Movement," Mississippi Valley Historical Review 38 (1952), 679-94. 
Congress. Meeting with Lincoln, Kasson corrected the misunderstanding and described Samuel Miller's qualifications to the president. ${ }^{43}$ On another occasion, Iowa Governor Samuel Kirkwood, Senator James Harlan, and several Iowa congressmen went to the White House to urge Lincoln to appoint Miller. At that meeting, the Iowans, assuming that Lincoln knew why they had come, launched into their case without mentioning Miller's name or the position to which they wanted him appointed. Lincoln, who was well aware of the Iowans' hopes, used the opportunity to humorous advantage. He "picked up his pen, and drawing a paper to him as if to make the appointment in compliance with their wishes, said to them, 'what is the office and whom do you wish to be placed in it?" "We wish," an astounded Harlan quickly replied, "to have Mr. Miller of Iowa chosen by you to the vacancy on the Supreme Bench." "Well, well," Lincoln replied, putting down his pen and pushing back the paper, "that is a very important position and I will have to give it serious consideration. I had supposed you wanted me to make some one a Brigadier General for you." The chagrined Iowans left with no assurances. ${ }^{44}$

As the process moved forward, Iowans back home and in Washington flooded Lincoln's desk with more material in support of Miller. In addition to the numerous letters from the Iowa bar and bench, Lincoln received written entreaties from Iowa's state legislature and "Iowa State Citizens." Wilson and Grimes

43. Kasson to Charles Aldrich, 10 November 1893, quoted in Henry Strong, "Justice Samuel Freeman Miller," Annals of Iowa 1 (1894), 241, 252. Daniel Miller represented Iowa in the Thirty-first Congress (1849-1851). Samuel Miller may have resented Lincoln's mistake as, during the war, Daniel Miller became an antiwar "copperhead." Although the two Millers were cordial to one another, in private Samuel dismissed Daniel as "a malcontent and a whiner." Keokuk Gate City, 10 October 1860.

44. Silver, Lincoln's Supreme Court, 66. Governor Kirkwood's avid support of Miller may also have been spurred by a desire to remove a political rival. In 1861 Miller made an abbreviated attempt to challenge Kirkwood for the governorship. For a discussion of the brief and muted rivalry between the two men, see Miller's letter to Samuel Kirkwood, 3 August 1861, Samuel Kirkwood Papers, State Historical Society of Iowa, Des Moines. For discussion of the efforts Iowans made on Miller's behalf and their meeting with Lincoln, see Cook, Baptism of Fire, 59, 68, 93, 111, 114, 121; Morton M. Rosenberg, Iowa on the Eve of the Civil War: A Decade of Frontier Politics (Norman, OK, 1972), 191; Keokuk Gate City, 3 and 5 August 1861; Fairman, Mr. Justice Miller, 36, 37, 48. 
also circulated petitions for Miller's appointment in the U.S. House and Senate and managed to procure the signatures of 28 senators and 120 congressmen. ${ }^{45}$

Lincoln, of course, had other concerns in the spring and summer of 1862 in addition to judicial reorganization and a possible appointment for Miller. In April the war in the West had taken a terrible turn. Horrific losses at the Battle of Shiloh, where twenty thousand men had been killed or wounded, convinced Lincoln and General Ulysses S. Grant that subduing the South would not be a quick or easy task. The war, Grant now concluded, could be won only by total conquest. For Lincoln, who did not want the war to become "a remorseless revolutionary struggle," this was a disheartening realization. In the East, matters also looked bleak. In May and June 1862, Stonewall Jackson's Confederate forces scored stunning successes in the Shenandoah Valley, while the carnage at the Battle of the Seven Days appeared to signal the start of a bloody summer. ${ }^{46}$ With the war escalating and the fate of the Union in doubt, pressing military matters slowed Lincoln's consideration of potential Supreme Court nominees.

When Lincoln did consider possible appointees for the Court, his primary criterion was finding justices who would support his war measures. Because the Civil War dominated all aspects of his presidency, the effect a proposed Court member might have on the conduct of the war took on paramount importance. Lincoln sought men likely to support both the war effort and even his most constitutionally suspect policies. Samuel Miller's supporters let Lincoln know that their man met those criteria. Outspoken in his opposition to the expansion of slavery, Miller had actively campaigned for Lincoln in Iowa in 1860. And, after the election, as civil war loomed, Miller urged crowds at Republican rallies to reject last-minute attempts at

45. Henry J. Abraham, Justices and Presidents: A Political History of Appointments to the Supreme Court, 2d. ed. (New York, 1985), 109; Fairman, Mr. Justice Miller, 50; Silver, Lincoln's Supreme Court, 65.

46. James Lee McDonough, Shiloh-In Hell before Night (Knoxville, TN, 1977); Robert G. Tanner, Stonewall in the Valley: Thomas J. "Stonewall" Jackson's Shenandoah Valley Campaign, Spring 1862 (Garden City, NY, 1976); McPherson, Battle Cry of Freedom, 413-14, 457-59. 
sectional compromise that would have required concessions to slaveholders. After Fort Sumter, Miller helped organize regiments in Iowa and gave fiery speeches demanding that the traitorous rebellion be crushed. ${ }^{47}$ Familiar with his steadfast Unionism, Miller's supporters emphasized his patriotism and unwavering commitment to Republican principles in their appeals to the president. Preoccupied with the war effort, Lincoln had to rely on the recommendations of others, and Miller's supporters provided him with plenty. ${ }^{48}$ Lincoln told one Iowan that "he had not known such a unanimous recommendation of any man for any office, and felt that he could not err in making the appointment of a Federal Judge so generally approved by an intelligent bar, and, not less important in such a crisis, by a patriotic people. ${ }^{\prime 49}$

IN THE END, Lincoln chose Miller without first meeting him. It is possible that Lincoln thought such a meeting was unnecessary, for the president knew men like Miller. From Miller's background and qualifications, the president must have recognized a familiar tale, for in many ways, Miller's past mirrored Lincoln's own. Born seven years apart in the same state, Lincoln and Miller both grew up on hardscrabble family farms in slaveholding Kentucky. Both men hated the mind-numbing, backbreaking existence on preindustrial farms, and in early adulthood they rejected the life of their parents. As a means to prominence and upward mobility, they both eventually chose a career in law and thrived in that profession. Gravitating to the Whig Party, Lincoln and Miller championed Henry Clay's American System of internal improvements, factories, banks, tariffs, and aggressive economic growth. They embraced the notion of a modern, urbanized America teeming with factories. "Lincoln fought his entire political life for industrialization," one historian has written, "and there was not a pastoral bone in

47. Keokuk Gate City, 14 July and 17, 23, 28, and 30 August 1860, 28 January, 19 April, and 25 May 1861.

48. Abraham, Justices and Presidents, 109.

49. Strong, "Justice Samuel Freeman Miller," 257. 
his body. ${ }^{\prime 50}$ Miller shared Lincoln's views. During his early career in southeastern Kentucky, he supported industrialization, urbanization, the national bank, and tariffs and hoped that Cassius Clay's vision of a "Kentucky System" would bring factories and economic salvation to his town. When he moved to Iowa, it was Keokuk's economic vitality, not the region's fertile soil, that attracted him. In Keokuk, Miller saw an embryonic Chicago, and he wanted to reap the benefits of having been there at the start as it grew into a major metropolis. When Lincoln grimly described a nonindustrial world where "all is cold and still as death-no smoke rises, no furnace roars, no anvil rings," he could have been describing Barbourville, the Kentucky town that Miller fled, or the Keokuk that might be if that city could not escape its disastrous debts to bondholders. ${ }^{5}$

Lincoln and Miller both also celebrated free labor, the right to rise in life, and the "self-made man." America was a remarkable land, Lincoln believed, where the "penniless beginner in the world labors for wages awhile, saves a surplus with which to buy tools and land, for himself; then labors on his own account another while, and at length hires another beginner to help him." "This," Lincoln proclaimed, "is free labor-the just and generous, and prosperous system which opens the way for all-gives hope to all, and energy and progress, and improvement of condition to all."${ }^{152}$ Lincoln had risen in life, and he was confident that in America others could, too. Miller shared Lincoln's views on this point. As a young man in the Barbourville Debating So-

50. Mark E. Neely, The Last Best Hope of Earth: Abraham Lincoln and the Promise of America (Cambridge, MA, 1993), 10, 11; G. S. Boritt, Lincoln and the Economics of the American Dream (Memphis, TN, 1978), 1, 14, 93, 101, 105; David Herbert Donald, Lincoln (New York, 1995), 110.

51. Michael A. Ross, "Hill-Country Doctor: The Early Life and Career of Supreme Court Justice Samuel Freeman Miller in Kentucky, 1816-1849," Filson Club History Quarterly 71 (1997), 430-62; idem, "Cases of Shattered Dreams," 201-39; Lincoln, quoted in Boritt, Lincoln and the Economics of the American Dream, 119. Both Lincoln and Miller have, on occasion, been inaccurately portrayed as men of the rural West. In popular mythology, Lincoln is sometimes depicted as a clever but folksy country lawyer. In Miller's biography, Charles Fairman describes Miller as an agrarian. Although Lincoln occasionally capitalized on his folksy image, such descriptions do not accurately depict either man.

52. Lincoln, quoted in Boritt, Lincoln and the Economics of the American Dream, 177; Donald, Lincoln, 234. 
ciety, Miller's unbridled optimism about his country had led him to argue that the American economic system did not unfairly favor the wealthy and that talent was more important than wealth in achieving success. ${ }^{53}$ Because slavery denied both blacks and nonslaveholding whites the opportunity to rise, both men hated the peculiar institution and moved west to get away from it. When the Kansas-Nebraska Act threatened to bring slavery to what had been free soil, both men vehemently opposed it. And when that act irreparably split the Whigs along sectional lines, Miller and Lincoln joined the Republican Party and never looked back.

The parallels between Lincoln and Miller are hardly startling, however. Theirs was a common story, played out many times in the antebellum West. America's expansion provided unprecedented opportunities, both for those seeking farmland and for men like Lincoln and Miller who chased urban, bourgeois dreams. Self-made men formed the backbone of the Whig and Republican Parties. Much of the support for both parties came from people who had succeeded in the nineteenth-century economy and who believed that others with talent and ambition should follow their example. ${ }^{54}$ Thus, when Miller's supporters told Lincoln of Miller's rural Kentucky roots, Whig background, career in law, antislavery views, and conversion to Republicanism, the president must have felt reassured. Based on Lincoln's wartime criteria for Court appointments, Miller was a worthy candidate.

But while they shared similar backgrounds and held many of the same views, the wartime priorities masked differences in economic philosophy between Lincoln and Miller, distinctions that in peacetime might have made Lincoln wary of Miller. After the Panic of 1857, Miller began to believe that capital had concentrated dangerously in the hands of parasitical financiers. Lincoln, on the other hand, still believed that capitalists, farmers, laborers, and merchants had a harmony of interests. Because Americans could rise, social mobility ensured that today's

53. Ross, "Hill-Country Doctor," 430-62.

54. Richardson, The Greatest Nation of the Earth, 15, 21; Eric Foner, Free Soil, Free Labor, Free Men: The Ideology of the Republican Party before the Civil War (New York, 1970), 16, 17. 
laborer could be tomorrow's capitalist. Lincoln did not believe the capitalist class had grown unduly large or powerful. Instead, he feared that attacks on capitalists, such as calls for the repudiation of debts, undermined property, and if property was not secure, the incentive to labor diminished. "Let not him who is houseless pull down the house of another," Lincoln admonished, "but let him labor diligently and build one for himself, thus by example assuring that his own shall be safe from violence when built." Although Lincoln was willing to tax the rich disproportionately to pay for the war, he almost certainly would have opposed Miller's attempts to manipulate Iowa law so that Iowa river towns could escape their contracted debts to eastern financiers. $^{55}$

In calmer times, factors besides slavery and the war certainly would have entered the nomination equation. Without wartime distractions, the Iowa river towns' attempts to escape their railroad debts through litigation would almost certainly have received some attention from Lincoln. In the years before slavery took center stage, Lincoln had been obsessed with economic issues, of which the repudiation of railroad bonds in Illinois was one. In other circumstances, Lincoln may well have asked Kirkwood, Harlan, Kasson, or the other Iowans pushing Miller's nomination where their man stood on municipal bonds. He would not have liked the answer. But in the whirlwind of civil war, Miller's views of bondholders did not surface. Miller was sound on race, slavery, and the war; that was all that was required.

ON JULY 16, 1862, the day after the enactment of the Judicial Reorganization Act, President Lincoln nominated Samuel Freeman Miller for the seat representing the new Ninth Circuit on the United States Supreme Court. He sent Miller's nomination to the Senate, where it was confirmed within half an hour. ${ }^{56}$ On

55. Collected Works, 7:259-60; Boritt, Lincoln and the Economics of the American Dream, 96, 98; Foner, Free Soil, Free Labor, Free Men, 20, 177.

56. Because Miller was in Washington when Lincoln announced his appointment, the process moved quickly from there. Swisher, The Taney Period, 828; Abraham, Justices and Presidents, 109. 
July 19, Miller received his commission, and on July 21 Chief Justice Taney administered Miller's oath of office.

Iowa's representatives in Washington "most heartily rejoiced. ${ }^{\prime \prime 7}$ They had, within the span of a few days, scored two dramatic successes, as both a trans-Mississippi circuit and the appointment of Miller became realities. In Iowa, Republicans cheered, anticipating that Miller would give their values a voice on the Court. The new justice, it was noted, brought with him a western view of the law that favored practicality over precedents. While some historians have charged Miller with having "little systematic approach to the law," Iowans saw this characteristic as a strength. Miller was a judge who sought to achieve results first and then found the arguments to justify those results. ${ }^{58}$ If justice demanded that river towns be free from their bond debts, for example, Miller would find a way. Unlike men from the tradition-bound East, Miller thought practically and was not awed "by the dust of antiquated precedents." "He is [the] model," the Keokuk Gate City trumpeted, "the beau ideal of a Western lawyer and a Western Judge and his advent to the Bench cannot fail to create a sensation even in that fossilized circle of venerable antiquities which constitutes the Bench of the Supreme Court of the United States. No better appointment has been made in our time." "The appointment is a most excellent one," Des Moines's Daily State Register declared, "and grateful to the people of Iowa."

While Iowans cheered, the eastern press met Miller's appointment with confusion. Miller was so little known that the New York Tribune mistook him for Daniel F. Miller (as Lincoln had earlier). "Mr. Miller's name is printed Samuel in the dispatches," the Tribune posited, "but we presume it is Daniel F. Miller, the first Whig member of Congress ever chosen from Iowa." ${ }^{\prime \prime 0}$ Most papers knew so little about Miller that they ran only an abbreviated dispatch stating that the appointment was

57. Report from Washington in Keokuk Gate City, 26 July 1862.

58. Silver, Lincoln's Supreme Court, 69; Fairman, Mr. Justice Miller, 22-24.

59. Keokuk Gate City, 18 July 1862; Silver, Lincoln's Supreme Court, 69; Daily State Register, 22 July 1862. See also Daily State Register, 19 July 1862; Burlington Hawkeye, 18 July 1862.

60. New York Tribune, 18 July 1862. 
made. ${ }^{61}$ One paper did manage to provide a thumbnail sketch of the new justice. "Many able men, being also modest, remain comparatively unknown," remarked Chicago's Christian Times. "In politics, Mr. Miller was originally a Whig, but when that party was destroyed by mint-juleps, his antislavery sentiments found early congeniality in the Republican organization." They also noted that Miller, unlike Swayne, was not wealthy. He is "economical in his way of life, but not parsimonious ... though not rich." ${ }^{162}$

Shortly after taking his oath of office, Miller returned to Keokuk to accept congratulations and organize his affairs. To celebrate, he and his wife, Eliza, hosted Iowa's prominent judges and lawyers at their house for a night of dining, toasts, and speeches. "We understand the evening passed very pleasantly," the Gate City reported, with "the distinguished host and his accomplished lady doing all in their power to render their visitors perfectly at home. The bar of Iowa, as well as the people, feel a just pride in being represented on the Bench of the Supreme Court by Judge Miller." The next day, Miller gave a rousing speech at a war meeting. ${ }^{63}$

Before leaving for Washington, Miller once again proved his commitment to a vigorous prosecution of the war. In August 1862, the Keokuk town council passed a law requiring suspected southern sympathizers to swear an oath of allegiance to the United States. Although Keokuk never suffered from the internecine warfare between unionists and southern sympathizers that was ongoing in neighboring Missouri, plenty of former southerners still lived in town, and their loyalty remained in doubt. The town council hoped to root out would-be Confederates with test oaths. Before heading to the East, Miller, now a United States Supreme Court justice, helped administer the oaths. If Lincoln wanted a justice who would support controversial war measures, he had picked the right man.

61. Chicago Tribune, 18 July 1862; New York Times, 17 July 1862; Baltimore Sun, 17 July 1862; Washington Daily Globe, 17 July 1862; New York World, 17 July 1862.

62. Christian Times (Chicago), 22 July 1862, reprinted in Keokuk Gate City, 12 August 1862.

63. Keokuk Gate City, 26 July 1862.

64. Keokuk Gate City, 8 August 1862. 
OF ALL OF LINCOLN'S APPOINTEES-he eventually filled five seats on the Court-Miller proved the most steadfast in his support of the president's war policies. During the conflict, Miller joined opinions that upheld Lincoln's view that the Confederacy was not a sovereign nation and the president's unilateral decision to blockade southern ports. ${ }^{65}$ Many cases involving Lincoln's wartime measures, moreover, did not reach the Court until after Appomattox and, with the hostilities ended, Justices David Davis, Salmon P. Chase, and Stephen J. FieldLincoln appointees all-allowed peacetime sensibilities to dictate their views. In famous cases such as Hepburn v. Griswold and Cummings v. State of Missouri, some of Lincoln's justices held that his wartime measures had been unconstitutional. Miller, however, unswervingly concluded that the chief executive's actions were constitutionally justified by the national crisis. ${ }^{66}$

In addition to becoming Lincoln's most resolute defender in the war powers cases, however, Miller also became the most radical anticapitalist voice on the Court-a voice that reflected Iowans' continuing anger at eastern bondholders. "I have met with but few things of a character affecting the public good of the whole country," Miller wrote in 1878, "that has shaken my faith in human nature as much as the united, vigorous, and selfish efforts of the capitalists. ${ }^{1{ }^{67}}$ In numerous dissents, Miller railed against his fellow justices because he thought they unfairly favored the wealthy and were beholden to the capitalist class. ${ }^{68}$ "It is the most painful matter concerned with my judicial life," Miller wrote of the Court's positions in the railroad bond

65. The Prize Cases, 67 U.S. 665 (1863); The Cornelius, 3 Wallace 214 (1865).

66. See, for example, Hepburn v. Griswold, 75 U.S. 603 (1870); Knox v. Lee, 79 U.S. 457 (1871); Ex Parte Milligan, 71 Wallace 2 (1866); Cummings v. State of Missouri, 71 U.S. 277 (1866); Ex Parte Garland, 71 U.S. 333 (1866); Ex Parte McCardle, 74 U.S. 506 (1869).

67. Miller to William Pitt Ballinger, 28 April 1878, Miller Papers, Library of Congress, box 2 , folder 3 .

68. See, for example, Gelpcke v. Dubuque, 68 U.S. 175 (1864); Meyer v. City of Muscatine, 68 U.S. 384 (1864); Butz v. City of Muscatine, 8 Wallace 575 (1869); Olcott v. The Supervisors, 83 U.S. 678 (1873); Pine Grove Township v. Talcott, 86 U.S. 666 (1874); Riggs v. Johnson County, 73 U.S. 166 (1868); Mercer County v. Hackett, 68 U.S. 83 (1864); Humboldt Township v. Long, 92 U.S. 642 (1876). See also Ross, "Cases of Shattered Dreams," 230-39. 
cases, "that I am compelled to take part in a farce whose result is invariably the same, namely to give more to those who have already, and to take away from those who have little the little they have. ${ }^{\prime \prime 9}$ These were views that President Lincoln, had he lived, almost certainly would not have shared. Because Lincoln opposed debt repudiation and believed that capitalists provided a valuable economic function, he may well have disapproved of this radical aspect of Miller's jurisprudence.

During the Civil War, Iowa's congressional delegation fought long and hard to have President Lincoln nominate a justice who shared Iowans' ideological views. As part of their strategy, they obstructed the passage of the Judicial Reorganization Act of 1862 until Iowa was placed in a circuit with other states with similar economic and political concerns. They then joined other Iowans in pressuring the president to appoint Samuel Freeman Miller, a man who had lived through the economic tribulations experienced by Iowa's river towns in the late 1850s. In the process, they successfully convinced Abraham Lincoln, a president who was understandably distracted by wartime concerns, to appoint a justice about whom he might later have had mixed feelings.

69. Miller to Ballinger, 13 January 1877, Miller Papers, box 2, folder 1. 
Copyright of Annals of Iowa is the property of State of Iowa, by \& through the State Historical Society of Iowa and its content may not be copied or emailed to multiple sites or posted to a listserv without the copyright holder's express written permission. However, users may print, download, or email articles for individual use. 